\title{
Association of Oral Contraceptives use with Breast Cancer and Hormone Receptor Status in Iraqi Women
}

\author{
Ahmed Z. Alsammarraie ${ }^{1 *}$, Ahmed A. Mubarak ${ }^{1}$, Ahmed S. Alnuaimi $^{2}$, Areege M. Kamal ${ }^{1}$ \\ ${ }^{1}$ Oncology Teaching Hospital, Baghdad, Iraq; ${ }^{2}$ Department of Community Medicine, College of Medicine, University of Baghdad, \\ Baghdad, Iraq
}

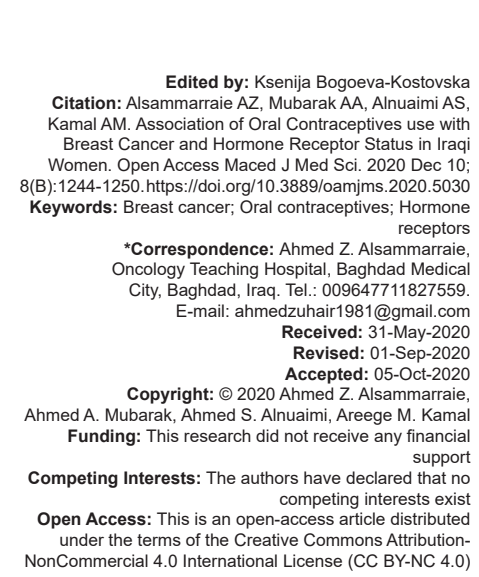

\section{Introduction}

Breast cancer is the most common cancer worldwide. In Iraq, breast cancer tops cancers for the past 30 years, accounting for $19 \%$ of all and $33.5 \%$ of female newly diagnosed cancer cases with incidence rate of about 25.8 per 100,000 female population in 2010 . It is the leading cause $(22.3 \%)$ of female cancer related deaths and the second cause (11.3\%) of all cancer-related deaths [1].

The association between breast cancer and exogenous hormonal intake has been a research focus for decades. The use of exogenous estrogen in the forms of postmenopausal hormone replacement therapy (estrogens alone or combined with progestins), premenopausal oral contraceptive pills, contraceptive injections, or implants has been repeatedly reported as possible risk factors of breast cancer, and they were shown to have a relative risk (RR) of <2 [2], [3]. In 1996, ever oral contraception (OC) users showed a small but significant increase risk of breast cancer $(R R=1.07$; confidence interval $[\mathrm{Cl}], 1.02-1.13)$ that was unrelated to the duration, dose or type of the preparation used and a slightly more risk among current users $(R R=1.24$; $\mathrm{Cl}, 1.15-1.33)$, which continues 10 years after stopping OC $(\mathrm{RR}=1.01 ; \mathrm{Cl}, 0.96-1.05)$ [4].

Depending on more than 10 cohort studies and 60 case-control studies published up to 2005 , International Agency of Research on Cancer (IARC) concluded in a monograph published in 2007 that the best evidence suggested an increase in risk for breast cancer among current and recent OC users with more increase are seen among females younger than 35 years of age who started taking $\mathrm{OC}$ when they were teenagers and that "OC are carcinogenic to humans" [5]. More recently, breast cancer incidence was shown to be significantly increased in ever users (odds ratio [OR], 1.08; $\mathrm{Cl}, 1.00-1.17)$ with a higher risk among recent OC use up to 5 years $(\mathrm{OR}, 1.21 ; \mathrm{Cl}, 1.04-1.41)$ [6].

Furthermore, association between OC use and hormone receptors status which is considered important prognostic and predictive markers of breast cancer has been proposed since 1987 [7]. Studies results, however, varied between strong association with $E R, P R$ negative cancers [8], [9] to little or no association [10], [11]. More 
importantly, none of these studies has been done in Middle East region, the population of which may differ in their contraceptive prevalence and breast cancer biological behavior, hence, may not typically reflect the condition in Iraq. Therefore, the current study aims to find the association between breast cancer risk and OC use among Iraqi females and examine the association OC use and ER and PR expression in breast cancer patients.

\section{Materials and Methods}

This is a hospital-based case-control study carried out in the Oncology Teaching Hospital in Baghdad Medical City during the period from January 1, 2018, to June 1, 2018. The study was approved by Oncology Teaching Hospital Ethical Committee and conformed to the principles of the Declaration of Helsinki of 1975. Informed written consent from study participants was secured. The interview was performed in a private setting.

\section{Study groups}

A total sample size of 500 was calculated to be sufficient to detect a statistically significant difference of $<0.05$ between cases/controls and the relative frequency of using $\mathrm{OC}$ implying an alpha error of 0.05 and a study power (1-beta) of 0.95 .

The study groups included 200 female patients with an established diagnosis of breast cancer (positive histopathology and receiving systemic therapy) with no positive family history of breast cancer and 300 agematched control selected from the first-degree relatives of the cases with no previous personal history of noninvasive breast tumors or benign proliferative breast diseases and no previous history of radiation therapy to match the genetic and environmental confounders. More than one control subjects were invited from each case when possible or available to overcome unavailability of relative controls for some cases. Participants with history of injectable or hormonal loaded intrauterine contraceptive device were excluded from the study.

A custom made close ended questionnaire form was filled by the participants who were personally interviewed gathering data about: Age, marital status, number of children, menstrual status, use of OC, type, duration of use, and time since first and last use. Hospital records were reviewed to obtain data about tumor site, histopathological type, stage, and hormonal receptors status.

\section{Statistical analysis}

Statistical analyses were performed using Statistical Package for the Social Sciences (IBM SPSS) software version 21 in association with Microsoft Excel 2013. All continuous data were presented as mean and standard deviation. OR and $95 \%$ Cls was used to measure the strength of association between two categorical variables. t-test or Chi-square was used to compare between groups when appropriate. Binary logistic regression analysis performed to assess the relationship between different variables if one or both of them follow normal distribution. $p<0.05$ was considered statistically significant.

\section{Results}

\section{Patient demographics}

The mean age of breast cancer patient and aged-matched healthy control participants was 48.5 (27-85) and 46 (20-79) years, respectively, which showed no statistical difference; almost half of them were postmenopausal as shown in Table 1.

Table 1: Study groups demographics and characteristics

\begin{tabular}{|c|c|c|c|c|c|}
\hline \multirow[t]{2}{*}{ Variable } & \multicolumn{2}{|c|}{ Healthy controls } & \multicolumn{3}{|c|}{ Breast cancer patients } \\
\hline & $\mathrm{n}$ & $\%$ & $\mathrm{n}$ & $\%$ & p-value \\
\hline Age group (years) & & & & & $0.15[\mathrm{NS}]$ \\
\hline Young $(<45)$ & 125 & 41.7 & 60 & 30 & \\
\hline Average (45-64) & 153 & 51 & 126 & 63 & \\
\hline Older $(\geq 65+)$ & 22 & 7.3 & 14 & 7 & \\
\hline \multicolumn{5}{|c|}{ Postmenopausal compared to menopausal } & $0.68[\mathrm{NS}]$ \\
\hline Reproductive age (premenopausal) & 181 & 60.3 & 117 & 58.5 & \\
\hline Postmenopausal & 119 & 39.7 & 83 & 41.5 & \\
\hline Parous compared to nulliparous & & & & & 0.001 \\
\hline Nulliparous & 20 & 6.7 & 31 & 15.5 & \\
\hline Parous & 280 & 93.3 & 169 & 84.5 & \\
\hline \multicolumn{6}{|l|}{ Tumor type } \\
\hline Invasive ductal carcinoma & - & & 191 & 95 & \\
\hline Invasive lobular carcinoma & - & & 9 & 5 & \\
\hline \multicolumn{6}{|l|}{ Tumor stage } \\
\hline I-II & - & & 74 & 37 & \\
\hline IIIIIV & - & & 126 & 63 & \\
\hline
\end{tabular}

The parity status was significantly different between the cases and controls ( $p=0.001)$ with $15 \%$ of the cases were nulliparous women compared to only $6.7 \%$ of the controls (Table 1 ).

\section{Breast cancer risk and OC}

As shown in Table 2, a significantly higher proportion $(49 \%)$ of breast cancer patients gave a positive history of OC use compared to healthy controls

Table 2: Breast cancer risk in OC users according to the age of first use

\begin{tabular}{|c|c|c|c|c|c|c|c|}
\hline \multirow[t]{2}{*}{ Variable } & \multicolumn{2}{|c|}{ Healthy control } & \multicolumn{3}{|c|}{ Breast cancer patients } & \multirow{2}{*}{$95 \% \mathrm{Cl}$} & \multirow[t]{2}{*}{$\mathrm{p}$-value } \\
\hline & $\mathrm{n}$ & $\%$ & $\mathrm{n}$ & $\%$ & OR & & \\
\hline \multicolumn{8}{|c|}{ Age of first use of $\mathrm{OC}$} \\
\hline Non-users & 193 & 64.3 & 102 & 51.0 & & & \\
\hline$<20$ & 2 & 0.7 & 7 & 3.5 & 6.62 & $(1.35-32.48)$ & 0.02 \\
\hline $20-24$ & 17 & 5.7 & 12 & 6.0 & 1.34 & $(0.61-2.9)$ & 0.465 [NS] \\
\hline $25-29$ & 19 & 6.3 & 18 & 9.0 & 1.79 & $(0.9-3.57)$ & 0.096 [NS] \\
\hline $30-39$ & 52 & 17.3 & 46 & 23.0 & 1.67 & $(1.05-2.66)$ & 0.029 \\
\hline$\geq 40$ & 17 & 5.7 & 15 & 7.5 & 1.67 & $(0.8-3.48)$ & 0.171 [NS] \\
\hline \multicolumn{8}{|c|}{ Age of first use of $O C \geq 20$ years } \\
\hline Non-user & 193 & 64.3 & 102 & 51 & & & \\
\hline$<20$ & 2 & 0.7 & 7 & 3.5 & 6.62 & $(1.35-32.48)$ & 0.02 \\
\hline$\geq 20$ & 105 & 35 & 91 & 45.5 & 1.64 & $(1.13-2.37)$ & 0.009 \\
\hline
\end{tabular}


(35.7\%). The type of OC used was combined pills, none of the patients or control have had used progesterone only pills. The risk of having breast cancer was significantly increased by $73 \%$ in subjects with a positive history of OC use compared to those who never used OC. When age at first use of OC was considered, OC use at the youngest age ( $<20$ years) associated with the highest increase in the risk of having breast cancer (6.62 times, $p=0.02$, Table 3 ) compared to non-users. The increased risk of having breast cancer for the remaining age groups in terms of first $\mathrm{OC}$ use ranged between $34 \%$ and $79 \%$ (Table 2). In addition, being older than 20 years at first OC use increased the risk of having breast cancer by $64 \%(p=0.009)$ compared to non-users (Table 2).

Table 3: Breast cancer risk in OC users according to the duration of $O C$ use and total $O C$ exposure time

\begin{tabular}{|c|c|c|c|c|c|c|c|}
\hline \multirow[t]{2}{*}{ Variable } & \multicolumn{2}{|c|}{ Healthy controls } & \multicolumn{3}{|c|}{ Cases (Breast Ca) } & \multirow[t]{2}{*}{$95 \% \mathrm{ClOR}$} & \multirow[t]{2}{*}{$\mathrm{p}$-value } \\
\hline & $\mathrm{n}$ & $\%$ & $\mathrm{n}$ & $\%$ & OR & & \\
\hline \multicolumn{8}{|c|}{ Duration of OC use (years) } \\
\hline Never user & 193 & 64.3 & 102 & 51 & & & \\
\hline$<1$ & 11 & 3.7 & 24 & 12 & 4.13 & $(1.94-8.77)$ & $<0.001$ \\
\hline $1-4$ years & 49 & 16.3 & 35 & 17.5 & 1.35 & $(0.82-2.22)$ & $0.234[\mathrm{NS}]$ \\
\hline$\geq 5$ years & 47 & 15.7 & 39 & 19.5 & 1.57 & $(0.96-2.56)$ & 0.07 [NS] \\
\hline Total & 300 & 100 & 200 & 100 & & & \\
\hline \multicolumn{8}{|c|}{ Total exposure time (OC use + quit time) } \\
\hline None users & 193 & 64.3 & 102 & 51.0 & & & \\
\hline$<5$ & 20 & 6.7 & 17 & 8.5 & 1.61 & $(0.81-3.21)$ & $0.177[N S]$ \\
\hline $5-14$ & 48 & 16.0 & 28 & 14.0 & 1.10 & $(0.65-1.86)$ & $0.712[\mathrm{NS}]$ \\
\hline $15-24$ & 23 & 7.7 & 23 & 11.5 & 1.89 & $(1.01-3.54)$ & 0.046 \\
\hline$\geq 25$ & 16 & 5.3 & 30 & 15.0 & 3.55 & $(1.85-6.82)$ & $<0.001$ \\
\hline Total & 300 & 100.0 & 200 & 100.0 & & & \\
\hline
\end{tabular}

The short duration of OC use of $<1$ year was associated with an exceptionally higher risk of having breast cancer $(\mathrm{OR}=4.13)$ compared to non-users. This may be attributed to recall bias. The short duration of use (1-4 years) marginally and non-significantly increase the risk by $35 \%$, while, 5 years or longer duration of OC use showed further increase numerically but was statically not significant.

In addition, the total OC exposure time which was calculated by adding the duration of using $\mathrm{OC}$ and the discontinuation time together was assessed against the risk of having breast cancer. The longer exposure time showed the highest risk to have breast cancer; exposure time of 15-24 years was associated with $89 \%$ increased risk ( $p=0.046)$ compared to non-users while, 25 years of exposure or more was associate with OR of $3.55(p<0.001)$, Table 3 . There was no correlation between OC use and cancer type or stage.

\section{Hormonal receptors status of breast cancer patients and OC use}

ER and/or PR positive cases were $150(75 \%)$ and $50(25 \%)$ were receptor negative. The association between the risk of having positive hormone receptors among breast cancer cases and age of first OC use, ever $\mathrm{OC}$ use, duration of $\mathrm{OC}$ use, and total exposure time are shown in Table 4. There was no obvious or statistically significant association.

\section{Discussion}

The association between exogenous steroid hormones and breast cancer development was the focus of research in the developed countries for the past 3 decades, yet the association of OC intake and breast cancer in some developing countries in particular Iraq has not been well addressed. Several studies have pointed out differences in demographical and pathological breast cancer characteristics in Iraqi patients compared to other western countries [12], [13]. Moreover the age of starting OC intake differs from other countries due to cultural and social factors prompting studying this potential risk factor in Iraqi population.

Table 4: The risk of having positive hormonal receptor by selected explanatory variables among breast cancer cases

\begin{tabular}{|c|c|c|c|c|c|c|c|}
\hline \multirow[t]{3}{*}{ Variable } & \multicolumn{4}{|c|}{ Hormone positive Breast $\mathrm{Ca}$} & \multirow[t]{3}{*}{ OR } & \multirow[t]{3}{*}{$95 \% \mathrm{Cl}$ OR } & \multirow[t]{3}{*}{$p$-value } \\
\hline & \multicolumn{2}{|c|}{ Both ER/PR negative } & \multicolumn{2}{|c|}{ Positive ER and/or PR } & & & \\
\hline & $\mathrm{n}$ & $\%$ & $\mathrm{n}$ & $\%$ & & & \\
\hline \multicolumn{8}{|c|}{ Age of first use of OC (20+ years) } \\
\hline Non-user & 26 & 52.0 & 76 & 50.7 & & & \\
\hline $20+$ & 23 & 46.0 & 68 & 45.3 & 1.01 & $(0.53-1.94)$ & 0.973 [NS] \\
\hline Total & 50 & 100.0 & 150 & 100.0 & & & \\
\hline \multicolumn{8}{|l|}{ Parity } \\
\hline Parous & 44 & 88.0 & 125 & 83.3 & & & \\
\hline Nullipara & 6 & 12.0 & 25 & 16.7 & 1.47 & $(0.56-3.81)$ & 0.432 [NS] \\
\hline \multicolumn{8}{|c|}{ History of ever using $\mathrm{OC}$} \\
\hline Negative & 26 & 52.0 & 76 & 50.7 & & & \\
\hline Positive & 24 & 48.0 & 74 & 49.3 & 1.05 & $(0.56-2)$ & $0.87[\mathrm{NS}]$ \\
\hline Total & 50 & 100.0 & 150 & 100.0 & & & \\
\hline \multicolumn{8}{|c|}{ Duration of OC use (years)-categories four } \\
\hline Never used & 26 & 52.0 & 76 & 50.7 & & & \\
\hline$<1$ & 6 & 12.0 & 18 & 12.0 & 1.03 & $(0.37-2.86)$ & 0.96 [NS] \\
\hline $1-5$ years & 10 & 20.0 & 25 & 16.7 & 0.86 & $(0.36-2.02)$ & 0.721 [NS] \\
\hline $5+$ years & 8 & 16.0 & 31 & 20.7 & 1.33 & $(0.54-3.25)$ & 0.537 [NS] \\
\hline Total & 50 & 100.0 & 150 & 100.0 & & & \\
\hline$<5$ & 6 & 12.0 & 11 & 7.3 & 0.63 & $(0.21-1.87)$ & 0.401 [NS] \\
\hline $5-14$ & 5 & 10.0 & 23 & 15.3 & 1.57 & $(0.54-4.56)$ & 0.404 [NS] \\
\hline $15-24$ & 7 & 14.0 & 16 & 10.7 & 0.78 & $(0.29-2.11)$ & 0.628 [NS] \\
\hline $25+$ & 6 & 12.0 & 24 & 16.0 & 1.37 & $(0.5-3.72)$ & 0.538 [NS] \\
\hline Total & 50 & 100.0 & 150 & 100.0 & & & \\
\hline
\end{tabular}


Reviewing literature showed variability in calculating the RR of $\mathrm{OC}$ use. This was in part, due to selecting bias resulting in difficulties in controlling cofounders. In this study, we selected the control group from the first-degree relatives of patients excluding women with past personal of breast cancer, to overcome the difficulty of determining the genetic predisposition of breast cancer and to reduce the ethnic, social and environmental variations between cases and controls to the minimum. We also excluded women with history of the previous radiation therapy, breast proliferative diseases and non-invasive tumors, and we agematched both patient and control groups, as all these factors known to increase risk of breast cancer to a greater extent than OC use [3].

Nulliparity was rated to increase risk of the breast cancer with (OR 1.67-1.9) [3]. In Iraqi society, $\mathrm{OC}$ is predominantly used by married fertile women with very little exceptions of some unmarried or infertile married women who use OC for stopping bleeding or menstrual cycles during limited periods like the fasting month (Ramadan) or pilgrimage when women should stop worship during the days of cycle, if not stopped by medications. This reduces the confounding chance of nulliparity as all the nulliparous participants, in this study, did not use OC during their lives.

The association between specific OC formulations and breast cancer risk remains uncertain. Few studies have looked into this, the largest compared $38 \mathrm{OC}$ formulations and failed to detect a specific OC formulation that increase breast cancer risk in a greater extent than other formulations [14]. While other study done in a younger age group has detected an increased risk in current users of triphasic regimens only [15], which is not marketed in Iraq according to the data of IARC monograph [5], [16]. Combined OC are the most commonly used pills by Iraqi women; however, most of the participants in the current study were uncertain of the OC formulation they had used and some used more than one formulation. This fact made the analysis of risk association of specific formulation difficult in addition to recall bias.

In the present study, ever users have increased risk of breast cancer by $73 \%$, this was consistent with the extensive evidence of $\mathrm{OC}$ association with breast cancer stated in IARC monograph, 2007 [16], and the more recent systemic review of Gierisch et al. [6]. Several case-control studies conducted in the neighboring countries, which share relatively similar demographic and cultural factors, have shown wide variation in results [17], [18]. Consistent with a Turkish and an Iranian studies [17], [19], we has shown a significant increase risk of breast cancer among OC users. Interestingly, the effect of early use of OC before age of 20 years further increased the risk of breast cancer among Iraqi females irrespective of duration of use and time since the last use. This is important in the view of the trend toward early marriage in Iraqi society and the WHO documented estimation of using contraception by $21 \%$ of young Iraqi females aged 15-19 years [20]. This finding may explain the stronger effect of larger total exposure time (time since first use) more than 15 years on breast cancer among Iraqi females. Consistent with IARC pooled study which concluded an increase in $\mathrm{RR}$ in the subgroup of women $<50$ years of age at diagnosis who had begun using $\mathrm{OC}$ when they were teenagers [21]. Conversely, Collaborative Group study in 1996 had found an increased risk of breast cancer in current users continued to 10 years after stopping OC $(\mathrm{RR}=1.07 ; \mathrm{Cl}, 1.02-1.13)$ but disappear then after [4]. All the previously mentioned studies failed to detect a time-dependent association of breast cancer with duration of OC use, except a cohort study of Van Hoften et al. [22] which showed an increased risk but only for more than 10 years-use in women older than 55 years $(\mathrm{RR}=2.1 ; \mathrm{Cl}, 1.1-4.0)$ [22]. In the present study, trend of positive association between duration of OC use and breast cancer risk was noted; however, that was statically not significant. The short use for $<1$ year has shown significant increase of cancer the risk, but this may be attributed to the recall bias of old short interval life events by the control group.

The relationship between hormone receptors status and known risk factors of breast cancers, including OC use, has been studied previously but in a lesser extent comparing to other breast cancer risk factors and summarized in Supplementary Table 1.

In our cohort, and consistent with many other studies [23], [24], [25], [26], [27], no significant association was found between the hormone receptor status and the ever OC users, age at first OC use, duration of use, age at diagnosis, or parity.

Conversely, some studies reported a significant increase in risk of ER/PR -ve breast cancers among OC users [28], [29], two of which recruited African American women only [8], [29], and other studies included only young aged women [28]. A recent large study from UK showed that this association is seen only among OC users for more than 5 years [30]. A single Indian study depicted a significant association of hormone positive (ER/PR +ve) breast cancers and pre and postmenopausal $\mathrm{OC}$ users which was confounded by the low prevalence of OC use in India [9].

\section{Conclusion}

Oral contraceptives use increases the risk of breast cancer among Iraqi females, especially with the early use before age of 20 years and those with longer exposure time and showed no association with hormone receptor status. 


\section{References}

1. Ministry of Health. Iraq Cancer Board, Iraqi Cancer Registry, Iraqi Cancer Registry, Republic of Iraq. New Delhi: Ministry of Health; 2016.

2. Morrow CP, Bundy BN, Kurman RJ, Creasman WT, Heller P, Homesley HD, et al. Relationship between surgicalpathological risk factors and outcome in clinical stage I and II carcinoma of the endometrium: A gynecologic oncology group study. Gynecol Oncol. 1991;40(1):55-65. https://doi. org/10.1016/0090-8258(91)90086-k

PMid:1989916

3. Singletary SE. Rating the risk factors for breast cancer Ann Surg. 2003;237(4):474-82. https://doi.org/10.1097/01. sla.0000059969.64262.87

PMid:12677142

4. Collaborative Group on Hormonal Factors in Breast Cancer. Breast cancer and hormonal contraceptives: Collaborative reanalysis of individual data on 53297 women with breast cancer and 100239 women without breast cancer from 54 epidemiological studies. Lancet (London, England). 1996;347(9017):1713-27. https://doi.org/10.1016/ s0140-6736(96)90806-5

PMid:8656904

5. IARC Working Group on the Evaluation of Carcinogenic Risks to Humans. Combined Estrogen-progestogen Contraceptives and Combined Estrogen-Progestogen Menopausal Therapy. Lyon, France: IARC Monographs on the Evaluation of Carcinogenic Risks to Humans; 2007. p. 1-528. https://doi.org/10.1016/ s0003-2670(97)89591-8

6. Gierisch JM, Coeytaux RR, Urrutia RP, Havrilesky LJ, Moorman PG, Lowery WJ, et al. Oral contraceptive use and risk of breast, cervical, colorectal, and endometrial cancers: A systematic review. Cancer Epidemiol Biomarkers Prev. 2013;22(11):1931-43. https://doi.org/10.1158/1055-9965. epi-13-0298

PMid:24014598

7. Stanford JL, Szklo M, Boring CC, Brinton LA, Diamond EA, Greenberg RS, et al. A case-control study of breast cancer stratified by estrogen receptor status. Am J Epidemiol. 1987;125(2):184-94. https://doi.org/10.1093/oxfordjournals.aje. a114519

PMid:3812427

8. Rosenberg L, Boggs DA, Wise LA, Adams-Campbell LL, Palmer JR. Oral contraceptive use and estrogen/progesterone receptor-negative breast cancer among African American women. Cancer Epidemiol Biomarkers Prev. 2010;19(8):2073-9. https://doi.org/10.1158/1055-9965.epi-10-0428

PMid:20647407

9. Tewari M, Pradhan S, Singh U, Shukla HS. Estrogen and progesterone receptor status in breast cancer: Effect of oral contraceptive pills and hormone replacement therapy. Breast (Edinburgh, Scotland). 2007;16(5):540-5. https://doi. org/10.1016/j.breast.2007.05.005

PMid:17587581

10. Cotterchio M, Kreiger N, Theis B, Sloan M, Bahl S. Hormonal factors and the risk of breast cancer according to estrogen-and progesterone-receptor subgroup. Cancer Epidemiol Biomarkers Prev. 2003;12(10):1053-60. https://doi.org/10.1093/aje/kwm216 PMid:14578142

11. Rosenberg L, Zhang $\mathrm{Y}$, Coogan PF, Strom BL, Palmer JR. A case-control study of oral contraceptive use and incident breast cancer. Am J Epidemiol. 2009;169(4):473-9. https://doi. org/10.1093/aje/kwn360
PMid: 19074777

12. Alwan N, Kerr D, Al-Okati D, Pezella F, Nidhal F. Comparative study on the clinicopathological profiles of breast cancer among Iraqi and British patients. Open Public Health J. 2018;11:177-91. https://doi.org/10.2174/1874944501811010177

13. Majid RA, Hassan HA, Muhealdeen DN, Mohammed HA Hughson MD. Breast cancer in Iraq is associated with a unimodally distributed predominance of luminal Type B over luminal Type A surrogates from young to old age. BMC Womens Health. 2017;17(1):27. https://doi.org/10.1186/ s12905-017-0376-0 PMid:28388952

14. Marchbanks PA, Curtis KM, Mandel MG, Wilson HG, Jeng G Folger SG, et al. Oral contraceptive formulation and risk of breast cancer. Contraception. 2012;85(4):342-50. https://doi. org/10.1016/j.contraception.2011.08.007 PMid:22067757

15. Beaber EF, Buist DS, Barlow WE, Malone KE, Reed SD, $\mathrm{Li} \mathrm{Cl}$. Recent oral contraceptive use by formulation and breast cancer risk among women 20 to 49 years of age. Cancer Res. 2014;74(15):4078-89. https://doi.org/10.1158/0008-5472. can-13-3400 PMid:25085875

16. IARC Working Group on the Evaluation of Carcinogenic Risks to Humans. Hormonal Contraception and Post-menopausal Hormonal Therapy. Lyon: IARC Monographs; 1998. p. 1-528.

17. Kuru B, Ozaslan C, Ozdemir P, Dinç S, Camlibel M, Alagöl H. Risk factors for breast cancer in Turkish women with early pregnancies and long-lasting lactation--a case-control study. Acta Oncol (Stockholm, Sweden). 2002;41(6):556-61. https:// doi.org/10.1080/02841860214964 PMid:12546529

18. KarimSM,BaeshenW, NeamatullahSN,BinB. Oralcontraceptives, abortion and breast cancer risk: A case control study in Saudi Arabia. Asian Pac J Cancer Prev. 2015;16(9):3957-60. https:// doi.org/10.7314/apjcp.2015.16.9.3957 PMid:25987068

19. Ghiasvand R, Maram ES, Tahmasebi S, Tabatabaee SH. Risk factors for breast cancer among young women in southern Iran. Int J Cancer. 2011;129(6):1443-9. https://doi.org/10.1002/ ijc. 25748

PMid:21064105

20. World Health Organization. Iraq-statistics Summary (2002-Present). Geneva: World Health Organization; 2002. Available from: https://www.apps.who.int/gho/data/node. country.country-IRQ. [Last accessed on 2020 Jan 17].

21. Huzell L, Persson M, Simonsson M, Markkula A, Ingvar C Rose $C$, et al. History of oral contraceptive use in breast cancer patients: Impact on prognosis and endocrine treatment response. Breast Cancer Res Treat. 2015;149(2):505-15. https://doi.org/10.1007/s10549-014-3252-8 PMid:25556354

22. Van Hoften $\mathrm{C}$, Burger $\mathrm{H}$, Peeters $\mathrm{PH}$, Grobbee DE, Van Noord PA Leufkens HG. Long-term oral contraceptive use increases breast cancer risk in women over 55 years of age: The DOM cohort. Int J Cancer. 2000;87(4):591-4. https://doi.org/10.1002/10970215(20000815)87:4<591::aid-ijc20>3.0.co;2-c PMid:10918202

23. Anderson KN, Schwab RB, Martinez ME. Reproductive risk factors and breast cancer subtypes: A review of the literature. Breast Cancer Res Treat. 2014;144(1):1-10. https://doi. org/10.1007/s10549-014-2852-7 PMid:24477977

24. Turkoz FP, Solak M, Petekkaya I, Keskin O, Kertmen N, Sarici F, et al. Association between common risk factors and molecular 
subtypes in breast cancer patients. Breast (Edinburgh, Scotland). 2013;22(3):344-50. https://doi.org/10.1016/j. breast.2012.08.005

PMid:22981738

25. Elwood JM, Godolphin W. Oestrogen receptors in breast tumours: Associations with age, menopausal status and epidemiological and clinical features in 735 patients. $\mathrm{Br} \mathrm{J}$ Cancer. 1980;42(5):635-44. https://doi.org/10.1038/bjc.1980.296 PMid:7459204

26. Lesser ML, Rosen PP, Senie RT, Duthie K, Menendez-Botet C, Schwartz MK. Estrogen and progesterone receptors in breast carcinoma: Correlations with epidemiology and pathology. Cancer. 1981;48(2):299-309. https://doi.org/10.1002/10970142(19810715)48:2<299::aid-cncr2820480215>3.0.co;2-2 PMid:7237401

27. Althuis MD, Fergenbaum JH, Garcia-Closas M, Brinton LA, Madigan MP, Sherman ME. Etiology of hormone receptordefined breast cancer: A systematic review of the literature. Cancer Epidemiol Biomarkers Prev. 2004;13(10):1558-68. https://doi.org/10.1016/s1047-2797(03)00136-4
PMid:15466970

28. Beaber EF, Malone KE, Tang MT, Barlow WE, Porter PL, Daling JR, et al. Oral contraceptives and breast cancer risk overall and by molecular subtype among young women. Cancer Epidemiol Biomarkers Prev. 2014;23(5):755-64. https://doi. org/10.1158/1055-9965.epi-13-0944

PMid:24633144

29. Bethea TN, Rosenberg L, Hong CC, Troester MA, Lunetta KL, Bandera EV, et al. A case-control analysis of oral contraceptive use and breast cancer subtypes in the African American breast cancer epidemiology and risk consortium. Breast Cancer Res. 2015;17(1):22. https://doi.org/10.1186/s13058-015-0535-x PMid:25849024

30. Work ME, John EM, Andrulis IL, Knight JA, Liao Y, Mulligan AM, et al. Reproductive risk factors and oestrogen/progesterone receptor-negative breast cancer in the breast cancer family registry. $\mathrm{Br} J$ Cancer. 2014;110(5):1367-77. https://doi. org/10.1038/bjc.2013.807

PMid:24548865 


\section{Supplementary Table}

Supplementary Table 1: Summary of studies which addressed the risk of hormone status in $\mathrm{OC}$ users

\begin{tabular}{|c|c|c|c|c|c|}
\hline Authors & Country & Year & $\mathrm{n}$ & OR & $p$-value \\
\hline Elwood et al. & UK & 1980 & 735 & 0.83 & NS \\
\hline Lesser et al. & USA & 1981 & 784 & NA & NS \\
\hline \multirow[t]{2}{*}{ McTiernan et al. } & USA & 1986 & 240 & $1.2+$ & NS \\
\hline & & & & $0.8-$ & NS \\
\hline \multirow[t]{2}{*}{ Stanford et al. } & USA & 1987 & 458 & $0.8+$ & NS \\
\hline & & & & $1.2-$ & NS \\
\hline \multirow[t]{2}{*}{ Cooper et al. } & USA & 1989 & 380 & $0.88+$ & NS \\
\hline & & & & $1.33-$ & NS \\
\hline \multirow[t]{2}{*}{ Huang et al. } & USA & 2000 & 783 & $1.5+$ & NS \\
\hline & & & & $1.2-$ & NS \\
\hline \multirow[t]{2}{*}{ Britton et al.* } & USA & 2002 & 1212 & $1.2+$ & NS \\
\hline & & & & $1.5-$ & $\mathrm{s}$ \\
\hline \multirow[t]{2}{*}{ McCredie et al.* } & Australia & 2003 & 618 & $1.1+$ & NS \\
\hline & & & & $0.9-$ & NS \\
\hline \multirow[t]{2}{*}{ Cotterchio et al. } & Canada & 2003 & 3276 & $0.9+$ & NS \\
\hline & & & & $1.3-$ & NS \\
\hline \multirow[t]{2}{*}{ Althuis et al.* } & USA & 2003 & 1375 & $1.6+$ & NS \\
\hline & & & & $3.1-$ & $\mathrm{s}$ \\
\hline \multirow[t]{2}{*}{ Tewari et al. } & India & 2007 & 300 & $2.5+$ pre & $\mathrm{s}$ \\
\hline & & & & $2.4+$ post & S \\
\hline Lumachi et al. & Italia & 2008 & NA & $R=0.22$ & $\mathrm{~s}$ \\
\hline \multirow[t]{2}{*}{ Kwan et al. } & USA & 2009 & 2280 & Luminal B 0.73 & $\mathrm{~s}$ \\
\hline & & & & TN 0.97 & NS \\
\hline \multirow[t]{3}{*}{ Rosenberg et al. ${ }^{* *}$} & USA & 2010 & 789 & $1.11+$ & NS \\
\hline & & & & $1.65-$ & S \\
\hline & & & & $0.9 \pm$ & NS \\
\hline Ma et al. & USA & 2010 & 1197 & NA & $\begin{array}{l}\text { NS any } \\
\text { subtype }\end{array}$ \\
\hline Phipps et al. & USA & 2011 & $\begin{array}{l}2610+ \\
307-\end{array}$ & NA & $\begin{array}{l}\text { NS any } \\
\text { subtype }\end{array}$ \\
\hline Islam et al. & Japan & 2011 & 706 & $\begin{array}{l}0.82 \text { luminal B } \\
069 \text { TN }\end{array}$ & $\begin{array}{l}\text { NS any } \\
\text { subtype }\end{array}$ \\
\hline Turkoz et al. & USA & 2013 & 1884 & $\mathrm{NA}$ & $\begin{array}{l}\text { NS any } \\
\text { subtype }\end{array}$ \\
\hline \multirow[t]{2}{*}{ Ritte et al. } & Europe & 2013 & $3567+$ & $0.9+$ & NS \\
\hline & & & 998- & $1.09-$ & NS \\
\hline \multirow[t]{2}{*}{ Work et al. } & UK & 2014 & 4011 & $0.83+>5$ years & $\mathrm{s}$ \\
\hline & & & & $1.35->5$ years & S \\
\hline \multirow[t]{3}{*}{ Beaber et al.* } & USA & 2014 & 985 & Age $20-39$ years & \\
\hline & & & & $3.5->5$ years current & $\mathrm{s}$ \\
\hline & & & & 3.7 TN >5 years current & $\mathrm{s}$ \\
\hline \multirow[t]{4}{*}{ Bethea et al. ${ }^{\star *}$} & USA & 2015 & $1848+$ & $1.15+$ & $\mathrm{s}$ \\
\hline & & & 1043- & $1.24-$ & s \\
\hline & & & 494 & $1.14 \mathrm{TN}$ & NS \\
\hline & & & $\mathrm{TN}$ & & \\
\hline
\end{tabular}

"The study included only young aged patients; **Studies included African Americans; HR+: Hormonal receptors ER or PR expressed breast cancers; HR: Breast cancer lacking both ER and PR; Users: OC users; NA: This data is not accessible; NS: Non-significant; S: Significant; Pre: Premenopausal patients: Post.: Postmenopausal patients; TN: Triple Negative breast cancers. 